\title{
BACTERIAL INFECTION PROFILES AND TUMOR BIOMARKERS IN EGYPTIAN LUNG CANCER PATIENTS
}

\author{
${ }^{1}$ Omnia E. Ismail; ${ }^{2 *}$ Sahar M.R.Radwan \\ ${ }^{1}$ Biochemistry Dept., Faculty of Pharmacy, Egyptian Russian University \\ ${ }^{2}$ Microbiology \& Immunology Dept., Faculty of Pharmacy, Al- Azhar University
}

\begin{abstract}
A substantial number of bacterial pathogens have been putatively linked to cancer. In patients with lung cancer, pneumonia is the most important complication and has a high mortality. However, the common pathogens causing pneumonia are not clear. Also there is a need for identification of circulating tumor biomarkers by highly specific and accurate blood tests that can be performed at any medical facility. For these reasons the aim of the present study is identifying the major bacterial species present in sputum of lung cancer patients complaining from pneumonia and to measure the serum level of tumor markers with the assessment of their clinical significance. Methods: 60 patients diagnosed for lung cancer; 44 non small cell lung cancers (NSCLC) \& 16 small cell lung cancers (SCLC); as well as 10 control normal healthy adults were included. The sputum of the patients \& control were cultured on different culture media for identification of bacteria. Minimum Inhibitory Concentration (MIC) was determined by Microscan. The serums of the same candidates were analyzed for angiopoietin-2 (Ang-2), survivin, Carcinoembryonic antigen (CEA) and Neuron - specific enolase (NSE). Results: E. coli was isolated from 15 sputum samples, $\alpha$ or non hemolytic Streptococci were isolated from 43, Staphylococcus aureus was isolated from 3, K. pneumonia was isolated from 14, P. aeruginosa in 2, other bacteria in 9, Proteus mirabilis in 1, Acintobacter sp. in 2, Enterobacter cloacae in 2, Morganella morganii in 2, Serratia sp. in 1 and Candida in 3. The isolated bacteria showed multidrug resistance to the tested antibiotics.
\end{abstract}

Serum Ang-2 was significantly higher in SCLC and NSCLC groups as compared to normal group. Mean value of serum survivin was significantly higher in SCLC group as compared to normal and NSCLC groups. While there was no significant increase of serum survivin level in NSCLC group as compared to normal group. Mean value of serum NSE was significantly higher in SCLC group and NSCLC as compared to normal group. Serum NSE was higher in SCLC than in NSCLC group but the difference was not statistically significant. Mean value of serum CEA was significantly higher in SCLC group and NSCLC as compared to normal group. Also the mean value of serum CEA in NSCLC was significantly higher than the mean value of SCLC group. Conclusion: The spectrum of pulmonary infection in patients with lung cancer is wide and depends on the underlying neoplasm and the immunologic deficit or deficits related to it, and to various treatment modalities. The development of drug resistance among common respiratory pathogens is of great concern and underscores the need for the appropriate use of antimicrobial agents and the importance of infection control.

Serum survivin may be a useful marker in diagnosis of SCLC and also for differentiation between SCLC and NSCLC. Serum Ang-2 may be a good marker for lung cancer. 


\section{INTRODUCTION:}

Clinical and experimental data suggest an association between the presence of bacterial and/or fungal infection and the development of different types of cancer, independently of chemotherapy-induced leucopenia. This has also been postulated for the development of lung cancer, however the prevalence and the exact species of the bacteria and fungi implicated, have not yet been described (Panagiotis, et al., 2011).

The lung is a common site of infection in patients with cancer. The spectrum of pulmonary infection depends on the underlying immunologic deficit or deficits. Experimental and clinical data correlate cancer development with the presence of certain pathogens, independently of chemotherapy-induced leucopenia (Pieper, et al., 1984; Szymankiewicz, et al., 2006; Dancewicz, et al., 2009). Most infections are caused by bacteria (Especially Gram negative), but viruses are being increasingly identified. Aetiological causes of infection include bacteria (most commonly Pseudomonas aeruginosa, Stenotrophomonas maltophilia, and Nocardia species), viruses (eg, respiratory syncytial virus, para-influenza virus, influenza virus A and B, and cytomegalovirus), and fungi (eg, Aspergillus, Fusarium, and Mucorales species, and Pneumocystis jirovecii) (Sandro, et al., 2008).

Antibiotic resistance is increasing, so too are infections caused by $S$. pneumoniae that are penicillin-resistant and infections caused by $P$ aeruginosa that are multidrugresistant (ie, resistant to at least three of five antipseudomonal agents: carbapenems; quinolones; piperacillin-tazobactam or ticarcillin-clavulanic acid; cefepime or ceftazidime; and aminoglycosides) (Hachem, et al., 2007). Treatment of bacterial pneumonia is increasingly difficult because of resistance, and fungal infections continue to cause many deaths. Prevention of viral infection is essential and can be effective. Nosocomial spread should be interrupted aggressively with a comprehensive approach to infection control (Sandro, et al., 2008).

Scientists strive to explore biomarkers and their possible role in the diagnosis, treatment and prognosis of lung cancer. Researchers are trying to develop better screening and treatment options in the fight against malignancy. Ideally, diagnostic procedures should be conducted rapidly, and stuff and equipment cost should be kept to a minimal level with limited complications for the patient. This rationale supports the need for identification of circulating tumor biomarkers by highly specific and accurate blood tests that can be performed at any medical facility. Neuron specific enolase (NSE) is a glycolytic enzyme expressed in small cell lung cancer (SCLC), it is a useful marker for detection of SCLC and also of clinical value in non small cell lung cancers (NSCLCs) (Ferrigino, et al., 2003).

Survivin is a multifunction protein that inhibits apoptosis, regulates cell division and enhances angiogenesis. Studies suggest that survivin is involved in cancer progression (Ansell, et al., 2004).

Angiopoietins play an important role in angiogenesis. Angiopoietin-2 promotes tumor angiogenesis by priming the vasculature and potentiating the effects of cytokines at the front of active neovascularization (Takanami, 2004). The aim of this study is to identify the major bacterial species present in sputum of lung cancer patients complaining from pneumonia, and to determine the antibiotic sensitivity of these isolates to different antibiotics. The second aim is to measure the serum level of tumor markers as angiopoietin-2, survivin, Carcinoembryonic antigen (CEA) and Neuron - specific enolase (NSE) with the assessment of their clinical significance. 


\section{Patients \& Methods:}

This study included 70 subjects; 60 patients diagnosed for lung cancer (44 non small cell lung cancers \& 16 small cell lung cancers) and 10 control normal healthy adults.

\section{Collection \& Culture of sputum}

A portion of the sputum was smeared on a microscope slide for a Gram stain. Another portion of sputum specimens were washed with an equal volume of sterile saline and the wash liquid discarded. An appropriate amount of sputum was then added to an equal amount of trypticase soy broth (TSB; Becton-Dickinson Company, Cockysville, MD, USA). The specimens were further diluted 1:10, 1:1,000 and 1:100,000 with TSB, and $10 \mu \mathrm{L}$ of each dilution were inoculated onto trypticase soy agar with 5\% sheep blood agar (BA) and McConkey agar plates (LabM). The BA and McConkey plates were incubated for 48-72 h. (Aaron, et al., 2004). Identification of bacteria was done by traditional methods according to Bailey \& Scott's, (2007). Microscan Positive Identification (PID) panel type 20 (Dade Behring, West Sacramento, CA) was used to confirm the identification of isolates.

\section{MIC for the isolated bacteria:}

MIC for the isolated bacteria was determined using Microscan Identification (PID) panel type 20 (Dade Behring, West Sacramento, USA).

\section{Specimens' collection \& storage for tumor markers detection:}

Five $\mathrm{ml}$ of venous blood samples were withdrawn by vacutainer system for patients $\&$ control. Blood samples were allowed to clot for 30 minutes and centrifuged at 4000 r.p.m. for 15 minutes \& sera were separated into aliquots and stored at $-80^{\circ} \mathrm{C}$ till the time of analysis.

\section{Determination of serum Survivin:}

Quantikine Human survivin Immunoassay (R \& D System, USA) kit was used for the determination of serum survivin according to manufacturer's instruction.

\section{Determination of serum Angiopoietin- 2:}

Quantikine Human Ang-2 Immunoassay (R\&D Systems, USA - catalogue number DANG20) kit was used for determination of serum angiopoietin- 2 according to the manufacturers instruction.

\section{Determination of serum Carcioembryonic antigen:}

Serum CEA concentrations were measured using electrochemiluminescent immunoassay (ECLIA) method by Elecsys 2010 analyzer (Roche Diagnostics, Germany).

\section{Determination of serum Neuron specific enolase:}

Serum NES concentrations were measured using (ECLIA) method by Elecsys 2010 analyzer (Roche Diagnostics, Germany)

\section{Statistical Analysis:}

All data were expressed as mean \pm standard error of mean $(\mathrm{X} \pm \mathrm{SEM})$. Descriptive statistics were performed using Microsoft Excel 2007. All analysis and graphics were performed using Graphpad prism (windows version 5; Graphpad software 2007).

Difference between mean were assessed by unpaired $t$ test for parametric data and Mann-Whitney test for non- parametric data. Differences were considered statistically significant at $\mathrm{P}<0.05$. 


\section{RESULTS:}

\section{Bacterial isolates:}

Sputum from the 60 lung cancer patients was cultured; the identified bacteria are represented in table (1). E. coli was isolated from 15 sputum samples, $\alpha$ or non hemolytic Streptococci were isolated from 43, Staphylococcus aureus was isolated from $3, \mathrm{~K}$. pneumonia was isolated from 14, P. aeruginosa in 2, other bacteria in 9, Proteus mirabilis in 1, Acintobacter sp. in 2, Enterobacter cloacae in 2, Morganella morganii in 2, Serratia sp. in 1 and Candida sp. in 3. While in the control group Gram negative bacteria was not found.

Table (1): Number \& percentage of isolated bacteria from lung cancer patients and control group.

\begin{tabular}{|c|c|c|}
\hline Isolated Bacteria & $\begin{array}{c}\text { Number (\%) } \\
\text { Lung Cancer } \\
\text { Patients }\end{array}$ & $\begin{array}{c}\text { Number }(\%) \\
\text { Control }\end{array}$ \\
\hline E. coli & $15(25)$ & - \\
\hline$\alpha$ or Non hemolytic Streptococci & $43(71.6)$ & $6(60)$ \\
\hline Staphylococcus aureus & $3(5)$ & $4(40)$ \\
\hline K. pneumoniae & $14(23.3)$ & - \\
\hline P. aeruginosa & $2(3.3)$ & - \\
\hline Other bacteria & $9(15)$ & $2(20)$ \\
\hline Proteus mirabilis & $1(1.6)$ & - \\
\hline Acintobacter sp. & $2(3.3)$ & - \\
\hline Enterobacter cloacae & $2(3.3)$ & - \\
\hline Morganella morganii & $2(3.3)$ & - \\
\hline Serratia sp. & $1(1.6)$ & - \\
\hline Candida sp. & $3(5)$ & $5(50)$ \\
\hline
\end{tabular}

K.: Klebsiella; P.: Pseudomonas; E.: Escherichia

\section{Mean Minimum Inhibitory Concentration (MIC) for the isolated bacteria:}

MIC was determined for the isolated bacteria against different antibiotics which are used mainly for treatment of respiratory tract infection; the results are represented in table (2) 
Table (2): Minimum Inhibitory Concentration (MIC) for the isolated microorganisms against the tested antibiotics:

\begin{tabular}{|l|l|l|l|l|l|l|}
\hline Bacteria & $\begin{array}{l}\alpha \text { or Non } \\
\text { hemolytic } \\
\text { Streptococci }\end{array}$ & $\begin{array}{l}\text { Staphylococcus } \\
\text { aureus }\end{array}$ & E. coli & $\begin{array}{l}\text { K. } \\
\text { pneumoniae }\end{array}$ & $\begin{array}{l}\text { P. } \\
\text { aeruginosa }\end{array}$ & $\begin{array}{l}\text { Proteus } \\
\text { mirabilis }\end{array}$ \\
\hline Amox/Clav & $>4 / 2(\mathrm{R})$ & $>4 / 2(\mathrm{R})$ & $>16 / 8(\mathrm{R})$ & $>16 / 8(\mathrm{R})$ & $>16 / 8(\mathrm{R})$ & $\leq 8 / 4(\mathrm{R})$ \\
\hline Ampicillin & $>8(\mathrm{R})$ & $>8(\mathrm{R})$ & $>16(\mathrm{R})$ & $>16(\mathrm{R})$ & $>16$ & $\leq 8$ \\
\hline Azitreonam & $\leq 2(\mathrm{~S})$ & $>4(\mathrm{R})$ & $>16(\mathrm{R})$ & $>16(\mathrm{R})$ & $>16(\mathrm{R})$ & $>16(\mathrm{R})$ \\
\hline Cefazolin & $16(\mathrm{R})$ & $>16(\mathrm{R})$ & $>16(\mathrm{R})$ & $>16(\mathrm{R})$ & $>16(\mathrm{R})$ & $\leq 8(\mathrm{~S})$ \\
\hline Cefepime & $>16(\mathrm{R})$ & $>16(\mathrm{R})$ & $>16(\mathrm{R})$ & $>16(\mathrm{R})$ & $>16(\mathrm{R})$ & $\leq 8(\mathrm{~S})$ \\
\hline Cefotaxime & $32(\mathrm{R})$ & $>32(\mathrm{R})$ & $>32(\mathrm{R})$ & $>32(\mathrm{R})$ & $>32(\mathrm{R})$ & $\leq 8(\mathrm{~S})$ \\
\hline Ceftriaxone & $32(\mathrm{R})$ & $>32(\mathrm{R})$ & $>32(\mathrm{R})$ & $>32(\mathrm{R})$ & $32(\mathrm{I})$ & $\leq 8(\mathrm{~S})$ \\
\hline Chloramphenicol & $\leq 8(\mathrm{~S})$ & $>16(\mathrm{R})$ & $>16(\mathrm{R})$ & $>16(\mathrm{R})$ & $>16(\mathrm{R})$ & $\leq 8(\mathrm{~S})$ \\
\hline Ciprofloxacin & $\leq 1(\mathrm{~S})$ & $>2(\mathrm{R})$ & $>2(\mathrm{R})$ & $2(\mathrm{I})$ & $\leq 1(\mathrm{~S})$ & $\leq 1(\mathrm{~S})$ \\
\hline Erythromycin & $\leq 0.5(\mathrm{~S})$ & $>4(\mathrm{R})$ & & & & $\leq 4(\mathrm{~S})$ \\
\hline Gentamycin & $\leq 4(\mathrm{~S})$ & $>8(\mathrm{R})$ & $\leq 4(\mathrm{~S})$ & $\leq 4(\mathrm{~S})$ & $\leq 4(\mathrm{~S})$ & $\leq 4(\mathrm{~S})$ \\
\hline Imipenem & $\leq 4(\mathrm{R})$ & $>8(\mathrm{R})$ & $\leq 4(\mathrm{~S})$ & $\leq 4(\mathrm{~S})$ & $\leq 4(\mathrm{~S})$ & $\leq 2(\mathrm{~S})$ \\
\hline Levofloxacin & $\leq 2(\mathrm{~S})$ & $>4(\mathrm{R})$ & $>4$ & $\leq 2(\mathrm{~S})$ & $\leq 2(\mathrm{~S})$ & $\leq 4$ \\
\hline Norfloxacin & $\leq 4$ & $>8(\mathrm{R})$ & $\leq 4$ & $>8(\mathrm{R})$ & 8 & \\
\hline Oxacillin & $>2(\mathrm{R})$ & $>2(\mathrm{R})$ & & & & \\
\hline Penicillin & $>8(\mathrm{R})$ & $>8(\mathrm{R})$ & & & & $\leq 2 / 38(\mathrm{~S})$ \\
\hline Rifampin & $\leq 1(\mathrm{R})$ & $>2(\mathrm{R})$ & & & & \\
\hline Trimeth/Sulfa & $\leq 2 / 38(\mathrm{~S})$ & $>2 / 38(\mathrm{R})$ & $>2 / 38(\mathrm{R})$ & $>2 / 38(\mathrm{R})$ & $\leq 2 / 38(\mathrm{~S})$ & \\
\hline M & & & \\
\hline
\end{tabular}

MIC (mg/L) R; resistant, I: Intermediate, S: sensitive, Blank: not determined

Table (2): Cont.

\begin{tabular}{|l|l|l|l|l|}
\hline $\begin{array}{c}\text { Bacteria } \\
\text { Antibiotic }\end{array}$ & $\begin{array}{l}\text { Acintobacter } \\
\text { sp. }\end{array}$ & $\begin{array}{l}\text { Enterobacter } \\
\text { cloacae }\end{array}$ & $\begin{array}{l}\text { Morganella } \\
\text { morganii }\end{array}$ & Serratia sp. \\
\hline Amox/Clav & $16 / 8$ & $>16 / 8(\mathrm{R})$ & $>16 / 8(\mathrm{R})$ & $>16 / 8(\mathrm{R})$ \\
\hline Ampicillin & $>16$ & $>16(\mathrm{R})$ & $>16(\mathrm{R})$ & $>16(\mathrm{R})$ \\
\hline Azitreonam & $>16$ & $>16(\mathrm{R})$ & $>16(\mathrm{R})$ & $16(\mathrm{I})$ \\
\hline Cefazolin & $>16$ & $>16(\mathrm{R})$ & $>16(\mathrm{R})$ & $>16(\mathrm{R})$ \\
\hline Cefepime & $>16(\mathrm{R})$ & $>16(\mathrm{R})$ & $>16(\mathrm{R})$ & $\leq 8(\mathrm{~S})$ \\
\hline Cefotaxime & $>32(\mathrm{R})$ & $>32(\mathrm{R})$ & $>32(\mathrm{R})$ & $>32(\mathrm{R})$ \\
\hline Ceftriaxone & $>32(\mathrm{R})$ & $>32(\mathrm{R})$ & $>32(\mathrm{R})$ & $\leq 8(\mathrm{~S})$ \\
\hline Chloramphenicol & $>16$ & $\leq 8(\mathrm{~S})$ & $>16(\mathrm{R})$ & $16(\mathrm{I})$ \\
\hline Ciprofloxacin & $\leq 1(\mathrm{~S})$ & $\leq 1(\mathrm{~S})$ & $>2(\mathrm{R})$ & $\leq 1(\mathrm{~S})$ \\
\hline Erythromycin & & & & $\leq 4(\mathrm{~S})$ \\
\hline Gentamycin & $\leq 4(\mathrm{~S})$ & $8(\mathrm{I})$ & $>8(\mathrm{R})$ & $\leq 4(\mathrm{~S})$ \\
\hline Imipenem & $>8(\mathrm{R})$ & $>8(\mathrm{R})$ & $\leq 4(\mathrm{~S})$ & $\leq 2(\mathrm{~S})$ \\
\hline Levofloxacin & $\leq 2(\mathrm{~S})$ & $\leq 2(\mathrm{~S})$ & $>4(\mathrm{R})$ & $\leq 4$ \\
\hline Norfloxacin & $\leq 4$ & $\leq 4$ & $>8$ & \\
\hline Oxacillin & & & & \\
\hline Penicillin & & & & \\
\hline Rifampin & & & $>2 / 38(\mathrm{R})$ & \\
\hline Trimeth/Sulfa & $\leq 2 / 38(\mathrm{~S})$ & $>2 / 38(\mathrm{R})$ & $\mathrm{S})$ \\
\hline
\end{tabular}

MIC (mg/L) R; resistant, I: Intermediate, S: sensitive, Blank: not determined 


\section{Serum Survivin:}

Table (3) and Figure (1) demonstrates the $\chi^{-} \pm$SEM for serum survivin (pg/dl) in normal, SCLC and NSCLC groups. The results showed that mean value of serum survivin was significantly higher in SCLC group as compared to normal and to NSCLC group. While there was no significant increase of serum survivin level in NSCLC group as compared to normal group.

Table (3): Serum Survivin (pg/dl) in normal, SCLC and NSCLC groups

\begin{tabular}{|c|c|c|c|}
\hline \multicolumn{3}{|c|}{ Survivin } \\
\hline Parameters & Normal & SCLC & NSCLC \\
\hline Number & 10 & 16 & 44 \\
\hline$\chi^{-} \pm$SEM & $50.6 \pm 3.5$ & $70.6 \pm 3.2$ & $55.9 \pm 2.0$ \\
\hline Median & 48.8 & 74.3 & 53.0 \\
\hline Range & $38.0-74.6$ & $53.0-84.1$ & $39.3-96.3$ \\
\hline $\begin{array}{c}\text { \% Change } \\
\text { from } \\
\text { Normal }\end{array}$ & -------- & $\begin{array}{c}39.35 \% \\
\text { increase }\end{array}$ \\
\hline
\end{tabular}

Figure (1): Mean \pm SEM of serum Survivin (pg/di) in normal, SCLC and NSCLC groups

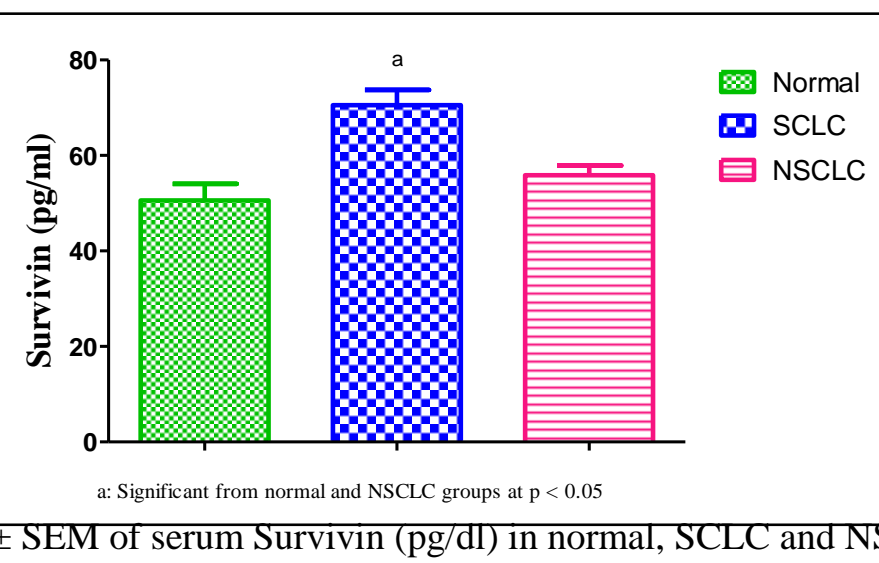

\section{Serum Angiopoietin-2:}

Table (4) and Figure (2) demonstrates the $\chi^{-} \pm$SEM for serum Ang-2 (pg/dl) in normal, SCLC and NSCLC groups. The results showed that mean value of serum Ang-2 was significantly higher in SCLC and NSCLC groups as compared to normal group. While there was no significant difference of serum Ang-2 level in SCLC group as compared to NSLC group. 
Table (4): Serum Ang-2 (pg/dl) in Normal, SCLC and NSCLC groups

\begin{tabular}{|c|c|c|c|}
\hline \multicolumn{4}{|c|}{ Angiopoietin-2 } \\
\hline Parameters & Normal & SCLC & NSCLC \\
\hline Number & 10 & 16 & 44 \\
\hline$\chi^{-} \pm$SEM & $1716 \pm 183.6$ & $2585 \pm 200.5$ & $3047 \pm 211.3$ \\
\hline Median & 1795 & 2514 & 2730 \\
\hline Range & $1076-2730$ & $1328-3884$ & $1171-6541$ \\
\hline $\begin{array}{c}\text { \% Change } \\
\text { from Normal }\end{array}$ & -------- & $\begin{array}{c}50.64 \% \\
\text { increase }\end{array}$ & $\begin{array}{c}77.56 \% \\
\text { increase }\end{array}$ \\
\hline
\end{tabular}

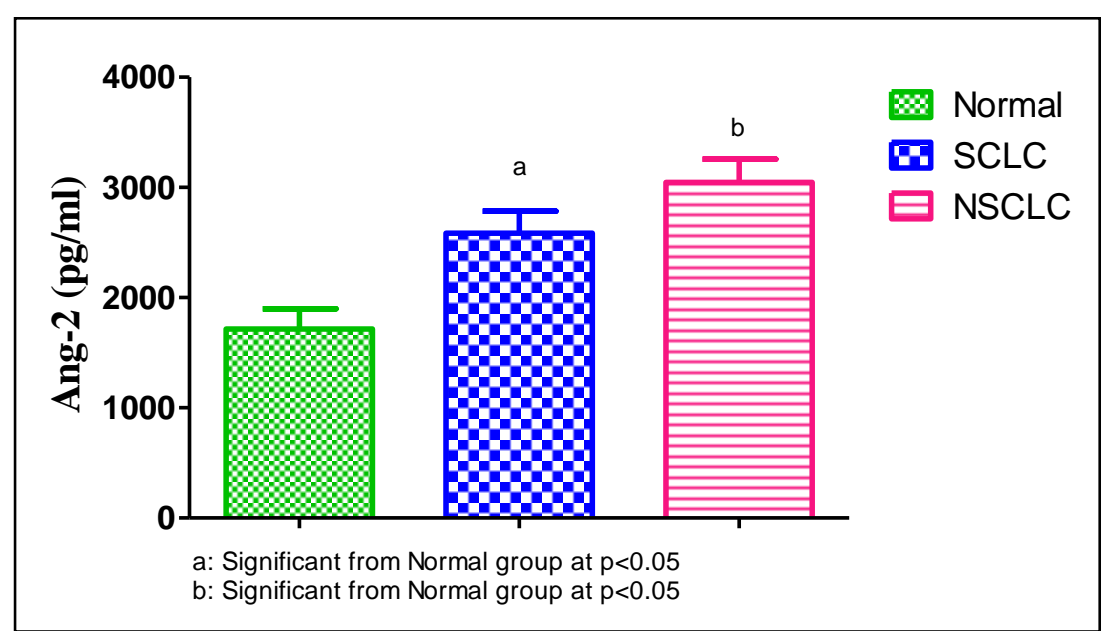

Figure (2): Mean \pm SEM of serum Ang-2 (pg/dl) in Normal, SCLC and NSCLC groups

\section{Serum Neuron specific enolase:}

Table (5) and Figure (3) demonstrates the $\chi^{-} \pm$SEM for serum NSE (ng/ml) in normal, SCLC and NSCLC groups. The results showed that mean value of serum NSE was significantly higher in SCLC group and NSCLC as compared to normal group. Serum NSE was higher in SCLC than in NSCLC group but the difference was not statistically significant. 
Table (5): Serum NSE (ng/ml) in Normal, SCLC and NSCLC groups

\begin{tabular}{|c|c|c|c|}
\hline \multicolumn{4}{|c|}{ Neuron Specific Enolase } \\
\hline Parameters & Normal & SCLC & NSCLC \\
\hline Number & 10 & 16 & 44 \\
\hline$\chi^{-} \pm$SEM & $4.5 \pm 0.7$ & $37.4 \pm 5.3$ & $29.1 \pm 2.9$ \\
\hline Median & 4.4 & 26.1 & 24.2 \\
\hline Range & $2.0-9.7$ & $14.9-70.6$ & $2.5-80$ \\
\hline $\begin{array}{c}\text { \% Change } \\
\text { from Normal }\end{array}$ & -------- & $\begin{array}{c}731.11 \% \\
\text { increase }\end{array}$ & $\begin{array}{c}546.67 \% \\
\text { increase }\end{array}$ \\
\hline
\end{tabular}

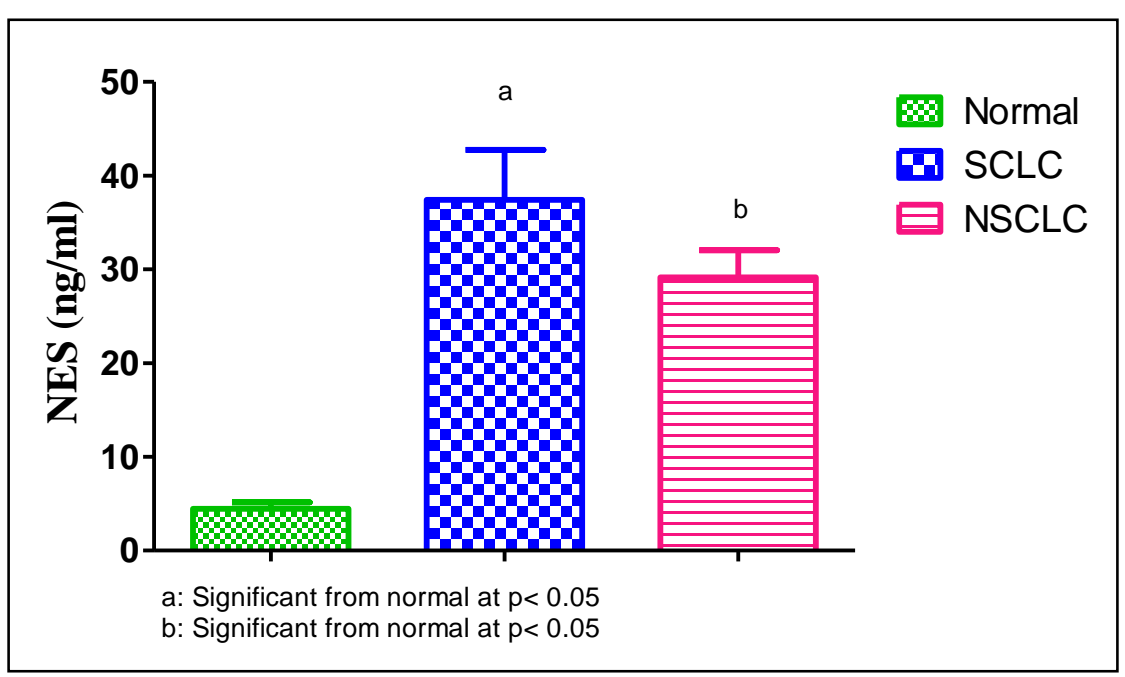

Figure (3): Mean \pm SEM of serum NSE (ng/ml) in normal, SCLC and NSCLC groups.

\section{Serum Carcinoembryonic antigen:}

Table (6) and Figure (4) demonstrate the $\chi^{-} \pm$SEM for serum CEA (ng/ml) in normal, SCLC and NSCLC groups. The results showed that mean value of serum CEA was significantly higher in SCLC group and NSCLC as compared to normal group. Also the mean value of serum CEA in NSCLC was significantly higher than the mean value of SCLC group.

Table (6): Serum CEA (ng/ml) in Normal, SCLC and NSCLC groups

\begin{tabular}{|c|c|c|c|}
\hline \multicolumn{4}{|c|}{ CEA } \\
\hline Parameters & Normal & SCLC & NSCLC \\
\hline Number & 10 & 16 & 44 \\
\hline$\chi^{- \pm \text {SEM }}$ & $1.6 \pm 0.08$ & $3.7 \pm 0.2$ & $16.1 \pm 3.4$ \\
\hline Median & 1.6 & 3.200 & 5.1 \\
\hline Range & $1.2-1.9$ & $2.9-5.1$ & $1.4-59.0$ \\
\hline $\begin{array}{c}\text { \% Change } \\
\text { from Normal }\end{array}$ & ------- & $\begin{array}{c}131.25 \% \\
\text { increase }\end{array}$ & $\begin{array}{c}906.25 \% \\
\text { increase }\end{array}$ \\
\hline
\end{tabular}




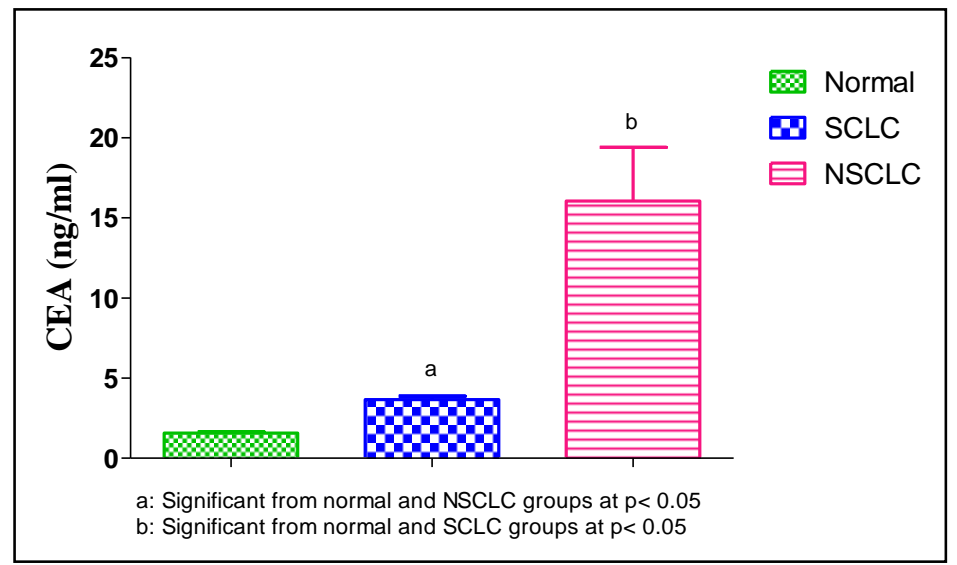

Figure (4): Mean \pm SEM of serum CEA (ng/ml) in normal, SCLC and NSCLC groups

\section{DISCUSSION:}

Bacterial infections traditionally have not been considered major causes of cancer. Recently, however, bacteria have been linked to cancer by two mechanisms: induction of chronic inflammation and production of carcinogenic bacterial metabolites.

Although most pulmonary infections in cancer patients are caused by a single pathogen, a substantial proportion might be polymicrobial, particularly in patients who are severely immunosuppressed or have multiple risk factors. Any combination of pathogens may be encountered, including multiple Gram-positive organisms (eg, S. aureus, streptococci, coagulase-negative staphylococci), Gram-positive and Gram-negative organisms (eg, $S$. aureus, $P$. aeruginosa), and occasionally anaerobic bacteria. Bacterial, fungal, and viral infections also coexist (Kenneth \& Rolston, 2001). In the present study, a single bacterial pathogen was isolated from sputum samples and also multiple Gram positives and Gram positive and Gram negative organisms were encountered.

In patients with lung cancer, pneumonia is the most important complication and has a high mortality. However, the common pathogens causing pneumonia are not clear. Rikimaru, et al. (2003) stated that they found bacteria that might colonize the tissue around the tumor in some lung cancer patients without infectious symptoms. These bacteria may have a significant role in causing febrile episodes after chemotherapy. Also a study done by Jean-Philippe, $\boldsymbol{e} t$ al., (2011) found that Gram-negative species were the most frequently identified bacteria in lung cancer patients. On the contrary Gram positive cocci were the most isolated bacteria in our work. We concluded that bacterial profile and clinical significance of these bacteria in lung cancer patients needs more study and the bacteria should be isolated from the cancerous tissue and tested for its pathogenicity and its' role in lung cancer.

In this study it was observed that all isolated bacteria were resistant to beta lactam antibiotics and sensitive for quinolone antibiotics except for Staph. aureus which was resistant to all tested antibiotics. Also Morganelle moganii was resistant to all antibiotics except for imipenem. This indicates that treatment of bacterial pneumonia is increasingly difficult because of resistance and may lead to most serious and life threatening lung infections.

Angiogenesis is an important process in carcinogenesis, and it plays a major role in lung cancer (Tas, et al., 2006). Although malignant tumors undergo massive tumor cell loss via central regression \& necrosis, the remaining tumor grows via active angiogenesis at the 
tumor margin. Angiopoietin-2 is reportedly critical regulator of this angiogenic process (Tanaka, et al., 2002; Takanami, 2004; Tas, et al., 2006). Angiopoietin - 2 operates in tumor angiogenesis, and it's over expression in lung cancer tissue is related to poor prognosis (Macchiarini et al., 1994). However, very few studies have examined the clinical implications of serum angiopoietin- 2 levels in lung cancer. This study showed that angiopoietin- 2 was important for differentiating lung cancer of both types from control subjects. This result is in agreement with Park et al. (2007) that studied serum angiopoietin-2 and VEGF in 110 patients with NSCLC and 40 healthy volunteers.

The other marker, Survivin, one of the inhibitors of apoptosis. Tas et al. (2006) reported that it shows a significant difference in the expression between malignant and normal adult cells, with very low to absent levels in the normal adult tissue, but increased to levels in a wide variety of solid tumors. This study based on the measurement of survivin concentrations in serum did not confirm these observations, we proved that survivin concentrations was not significantly different between normal and NSCLC, but there was significant difference in concentrations between SCLC compared to normal and NSCLC. This discrepancy between results may be due to that most previous studies on apoptosis have evaluated survivin expression in frozen tissue by reverse transcriptase polymerase chain reaction (RT-PCR) and/ or in paraffin- embedded materials by immunohistochemistry (IHC) not by ELISA.

Neuron specific enolase is a glycolytic enzyme expressed in brain tissue and amine precursor uptake and decarboxylation (APUD) cells, and can occur in medullary-thyroid carcinoma and in small cell lung cancer. Many studies have evaluated serum NSE as a tumor marker for lung cancer. Lee and Chang (2005); and Mumbarkar et al. (2006) proved that the level of NSE was significantly elevated in lung cancer group when compared to the healthy controls. NSE also showed significantly increase in SCLC when compared to other histological types of lung cancer.

Carcinoembryonic antigen is one of the carcinofetal antigens produced during embryonal and fetal development, reaching its highest fetal serum concentration in the 22nd gestational week. . An elevation of the concentration of CEA in blood and other body fluids is due to a combination of factors: increase in the number of cells producing CEA, increased synthetic rate in malignant cells, and decreased ability to use normal pathways of excretion from the body. In this study serum level of CEA was measured in both SCLC and NSCLC and the results were compared with the serum level of normal group. our results were in agreement with Lee and Chang, (2005); and Charalabopoulos et al. (2007).

In conclusion, Angiopoietin-2 is a useful marker for evaluating lung cancer but serum survivin has no clinical significance in diagnosis of NSCLC and further studies should clarify their clinical validity and prognostic implications. Also Serum NSE is a useful marker in diagnosis of lung cancer and Serum CEA is a useful marker in diagnosis of lung cancer specially NSCLC.

\section{REFERENCES:}

Aaron, S.D. ; D. Kottachchi, W.J. Ferris, K.L. Vandemheen, M.L. St. Denis, A. Plouffe, S.P. Doucette, R. Saginur, F.T. Chan, K. Ramotar (2004): Sputum versus bronchoscopy for diagnosis of Pseudomonas aeruginosa biofilms in cystic fibrosis. Eur Respir J; 24: 631-637

Ansell, SM.; Arendt, BK.; Grote, DM; Jelinek, DF; Novak, AJ; and Fielding, A. (2004): Inhibition of survivin expression suppresses the growth of non- Hodgkin's lymphoma. Leukemia, 18: 616- 623. 
Bailey \& Scott's, (2007): Diagnostic Microbiology, Twelfth edition, Betty, A.; Daniel, F; \& Alice, S. Mosby Elsevier, 11830 Westline Industrial Drive. St. Louis, Missouri 63146.

Charalabopoulos, K.; Karakosta, A.; Bablekos, G.; Golias, C.; Charalabopoulos, A.; Tsanou, E.; Peschos, D.; Zoganas, L; \& Batistatou, A. (2007): CEA levels in serum and BAL in patients suffering from lung cancer: correlation with individuals presenting benign lung lesions and healthy volunteers. Med Oncol. 24 (2): 219-225.

Dancewicz, M; et al (2009): [Bronchial bacterial colonization in patients with lung cancer]. Pneumonol Alergol Pol, 77(3):242-7.

Ferrigino, D.; Buccheri, G.; and Giordano, $C$ (2003): Neuron- specific enolase is an effective tumor marker in non- small cell lung cancer (NSCLC). Lung Cancer, 41: $311-320$

Hachem, RY; Chemaly, RF; Ahmar, CA; et al. (2007):.Colistin is effective in treatment of infections caused by multidrug-resistant Pseudomonas aeruginosa in cancer patients. Antimicrob Agents Chemother; 51: 1905-11.

Jean-Philippe Lanoix; Emilie Pluquet; Francois Xavier Lescure; Houcine Bentayeb; Emmanuelle Lecuyer; Marie Boutemy; Patrick Dumont; Vincent Jounieaux,;Jean Luc Schmit; Charles Dayen and Youcef Douadi (2011): Bacterial infection profiles in lung cancer patients with febrile neutropenia. $B M C$ Infectious Diseases, 11:183

Kenneth, V. I.; \& Rolston, MD. (2001): The spectrum of pulmonary infections in cancer patients. Current Opinion in Oncology 2001, 13:218-223.

Lee, JH. and Chang, JH., (2005): Diagnostic utility of serum and pleural fluid carcinoembryonic antigen, neuron-specific enolase, and cytokeratin 19 fragments in patients with effusions from primary lung cancer. Chest. 128 (4): 2298-2303.

Macchiarini, P; Fontanini, G; Hardin, M J; et al. (1994): Relation of neovascularisation to metastasis in non- small cell lung cancer invading the thoracic inlet. Ann Thorac Surg; 57, 1534-1539

Mumbarkar, PP.; Raste, AS.; and Ghadge, MS., (2006): SIGNIFICANCE OF TUMOR MARKERS IN LUNG CANCER. Indian Journal of Clinical Biochemistry 21 (1): 173-176.

Panagiotis Apostolou; Aggeliki Tsantsaridou; Ioannis Papasotiriou; Maria Toloudi; Marina Chatziioannou and Gregory Giamouzis (2011): Bacterial and fungal microflora in surgically removed lung cancer samples. Journal of Cardiothoracic Surgery, 6:137

Park, JH.; Park, KJ.; Kim, YS.; Sheen, SS.; Lee, KS.; Lee, HN.; Oh, YJ. and Hwang, SC., (2007): Serum angiopoietin-2 as a clinical marker for lung cancer. Chest. 132 (1): 200-206.

Pieper, R; Book, K; \& Nord, CE (1984): Microbial flora associated with pulmonary neoplasms. Scand J Thorac Cardiovasc Surg 1984, 18(3):259-61.

Rikimaru, T.; Mitui, T.; R. Gohara; M. Ichiki; Y. Sueyasu; H. Aizawa (2003): Clinical significance of bacteria isolated from bronchial lavage fluid in patients with lung cancer. Proc Am Soc Clin Oncol 22: (abstr 2998)

Sandro Vento; Francesca Cainelli; \& Zelalem Temesgen (2008): Lung infections after cancer chemotherapy. Lancet Oncol; 9: 982-92. 
Szymankiewicz, M; Kowalewski, J; \& Dancewicz, M (2006): [Bacteriological and mycological analysis of material taken from lower respiratory tract in patients with malignancy]. Pol Merkur Lekarski, 21(123):218-22.

Takanami, I. (2004): Overexpression of Ang-2 mRNA in non- small cell lung cancer: association with angiogenesis and poor prognosis. Oncol Rep; 12, 849- 853

Tanaka, F.; Ishikawa, S.; Yanagihara, K.; Miyahara, R.; Kawano, Y.; Li, M.; Otake, Y. and Wada, H., (2002): Expression of angiopoietins and its clinical significance in non-small cell lung cancer. Cancer Res. 62 (23): 7124-7129.

Tas, F; Duranyildiz, D; Oguz, H; et al., (2006): Serum vascular endothelial growth factor (VEGF) and BCL-2 levels in advanced stage non- small cell lung cancer. Cancer Invest; 24, 576- 580

$$
\begin{aligned}
& \text { صورة العدوي البكتيرية ودلالات الاورام في مرضي سرطان الرئة المصريين } \\
& \text { امنية اسماعيل عزت و سحر محمد رمزي السيد رضوان' } \\
& \text { ا قسم الكيمياء الحيوية ، كلية الصيدلة ، الجامعة المصرية الروسية }
\end{aligned}
$$

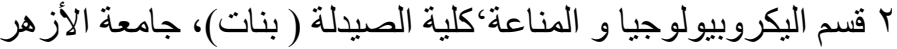

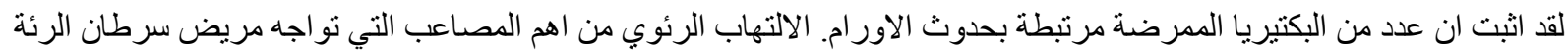

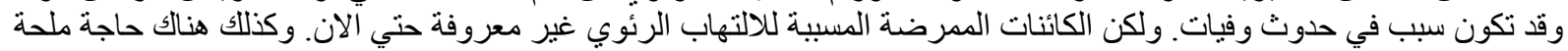

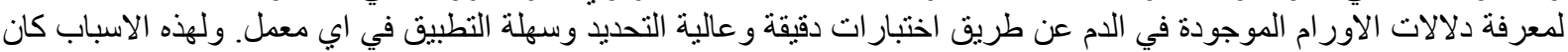

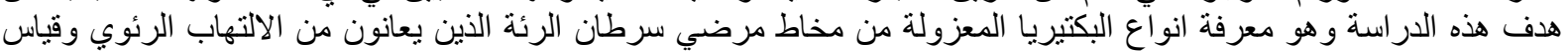

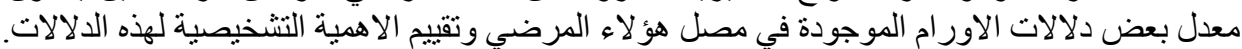
الطرق المستخدمة في البحث:

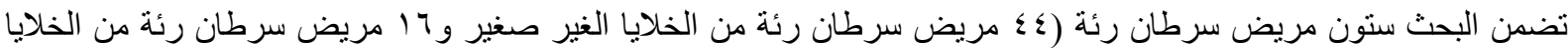

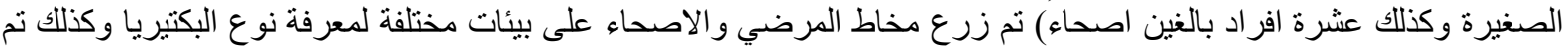

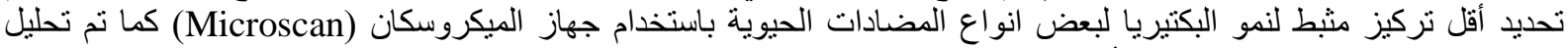

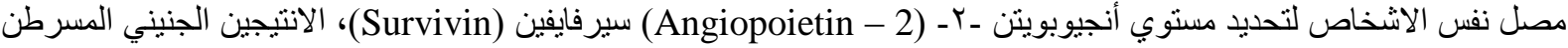
(Carsinoembryonic antigen)

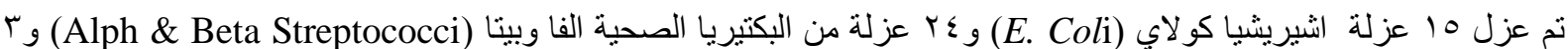

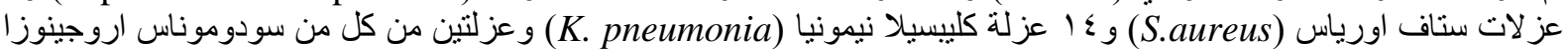

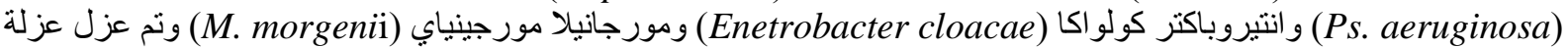

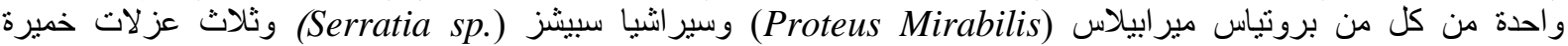
وقد اظهرت البكتبريا المعزولة مقاومة لاكثر من واحد من المضادئ (Candida sp.)

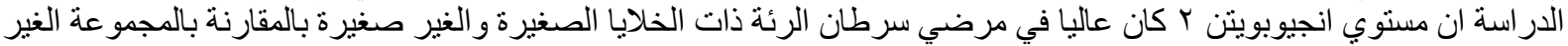

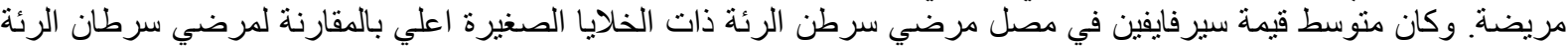

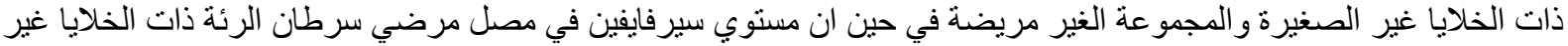

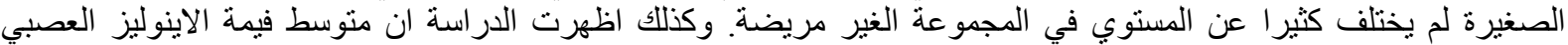

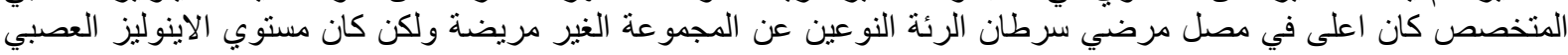

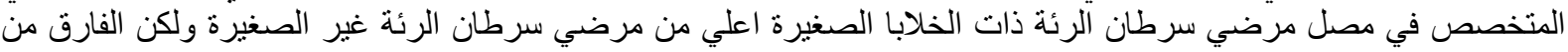

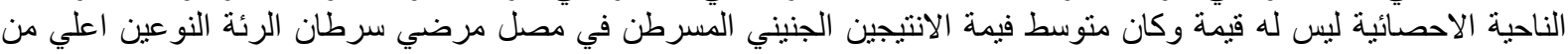

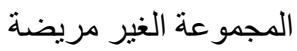

الخلاصة.

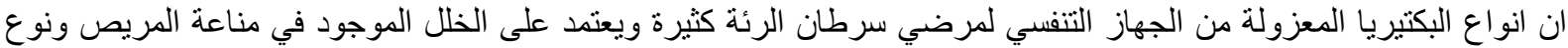

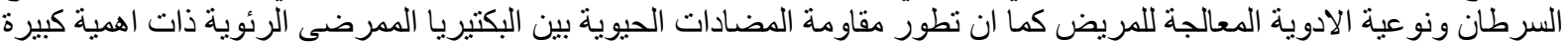

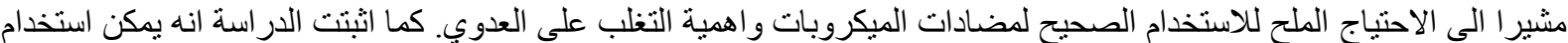

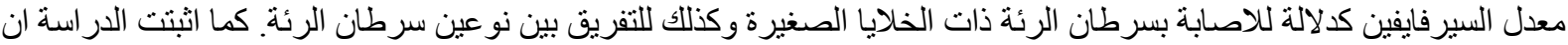

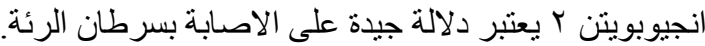

